\title{
Geography of agricultural exports from Ukraine
}

\author{
Ihor Kholoshyn ${ }^{1}$, Svitlana Mantulenko ${ }^{1 *}$, Accola Sharon Joyce ${ }^{2}$, Daniel Sherick ${ }^{2}$, Talgat Uvaliev $^{3}$, and Victoria Vedmitska $^{1}$ \\ ${ }^{1}$ Kryvyi Rih State Pedagogical University, 54, Gagarina Ave, Kryvyi Rih, 50086, Ukraine \\ ${ }^{2}$ Ryan Research International, 51 Skymountain Circle Chico, California 95928, USA \\ ${ }^{3}$ Abai Kazakh National Pedagogical University, Almaty, Dostyk str. 13, 050010/A26F0X3, Kazakhstan
}

\begin{abstract}
Based on the generalization and systematization of scientific and accounting data, the article considers agriculture as one of the leading sectors of the Ukrainian economy, providing $50 \%$ of foreign exchange earnings from exports of all goods from the country. The structure and geography of agricultural exports from Ukraine are analyzed. The existing export potential of the studied sector of the national economy and the level of self-sufficiency of Ukraine in agri-food products are revealed. Four specialization types of agricultural exports from Ukrainian regions are established: areas with dominance in export of animal origin products; areas with a dominance in the export of plant products; areas with a predominance in the export of animal or vegetable origin fats and oils; area, with mixed export specialization. Recommendations for the reprofiling of agricultural production in a number of the country's regions in order to increase exports of this product type.
\end{abstract}

\section{Introduction}

The agricultural sector is a competitive sector of the economy, able to fill the budget of Ukraine along with such traditional industries as metallurgy, chemical industry, mechanical engineering and others. At present, agriculture is a strategically important part of the country's economy, which forms a significant share of export earnings. By estimation of some world leading economists, Ukraine is able to provide food to more than 150 million people according to its scientific and resource potential [1].

To ensure further growth of agricultural exports and increase of its efficiency, a detailed scientific approach is necessary, taking into account the regional specifics of agricultural development in Ukraine. The issues of commercial and geographical structure of agricultural exports were investigated, the export stream guidelines of agricultural goods were considered in these works. The available export potential of the studied sector of national economy and Ukraine's agri-food products selfsufficiency level were analyzed in them [2, 3, 4, 5, 6, 7].

The research and publications analysis indicates that scientists do not pay attention to the questions concerning the geographical features of agricultural export specialization of Ukrainian regions, the solution of which may contribute to the development of regional export strategy of the country's agro-industrial complex. In general, this provided the timeliness of this work.

The purpose of the study is to highlight the geographical features of agricultural exports from Ukraine.
The information basis of this work was a variety of statistical material collected from various official sources: the State Statistics Service of Ukraine, the State Fiscal Service of Ukraine, the State Customs Service of Ukraine, the Ministry of Agrarian Policy and Food of Ukraine, the UN Food and Agriculture Organization [8, 9, 10, 11, $12,13,14]$.

The actual material was processed by methods of mathematical statistics [9]. Cartographic material was obtained by using geo-information systems [15].

\section{Results and discussion}

The potential of Ukraine's agriculture today exceeds coniderbly the needs of the domestic market. As a result, there is a sharp increase in the share of agricultural products in the country's good exports (Fig. 1): less than $15 \%$ in 2010 and more than a third of total exports in 2019. Thus, agricultural industry owing to higher yields, the increased agricultural production along with extending demand for it among foreign consumers and opening new markets, has recently become one of the leading sectors of Ukraine's economy. And all this is being observed with an evident decline in other sectors of the economy. According to the State Statistics Service, in January 2020 the share of agricultural products in Ukraine's total exports reached 50\% [9].

In monetary terms, foreign exchange earnings from agricultural products in 2010 amounted to $\$ 4.75$ billion, and more than $\$ 14$ billion in 2019 .

As for the structure of exports of Ukrainian agricultural products, as presented in Fig. 2, the majority

\footnotetext{
$\overline{{ }^{*} \text { Corresponding author: mantulenkokdpu@ukr.net }}$
} 
are crop products (68\%). Fats and oils account for $25 \%$ and animal products for only $7 \%$.

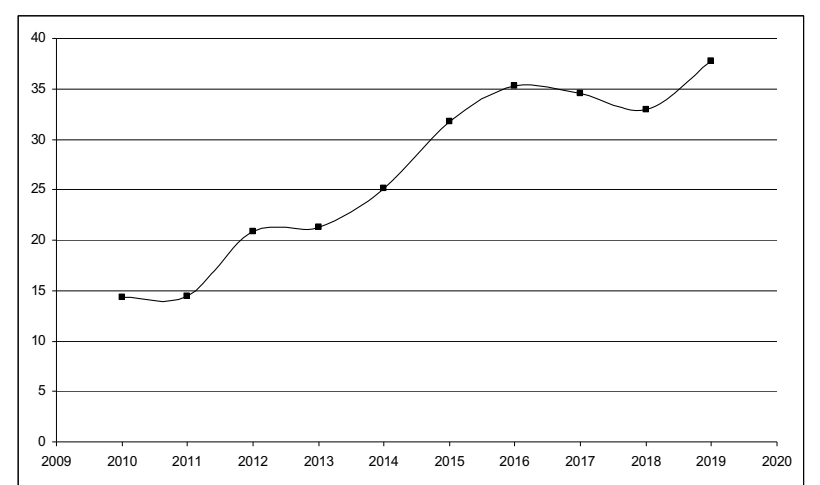

Fig. 1. The share of agricultural products (in\%) in exports of goods from Ukraine in the period from 2010 to 2019 (according to the State Statistics Service of Ukraine).

Analyzing the dynamics of agricultural product exports from Ukraine for the period from 2010 to 2019 (Fig. 3) it is obvious that animal products exports remained practically at the same level. There was only a slight decline in the period of 2015-2016. In general, this decline is typical for all agricultural products exports and is associated primarily with hostilities in the Donbass and the loss of the Russian market. Later on, a significant rise of plant origin products, fats and oils export one can observe. This especially relates to crop products. Thus, in 2019, the exports of plant origin agricultural products exceeded in monetary terms almost three times in 2010. For fats and oils - almost twice.

There are several reasons for this. Firstly, new markets are being developed by Ukrainian farmers. Secondly, the cultivation of agricultural products, that are in demand abroad, is significantly increasing. Thirdly, the attitude of state and commercial organizations to agricultural producers as potentially promising players in the foreign exchange market is changing.

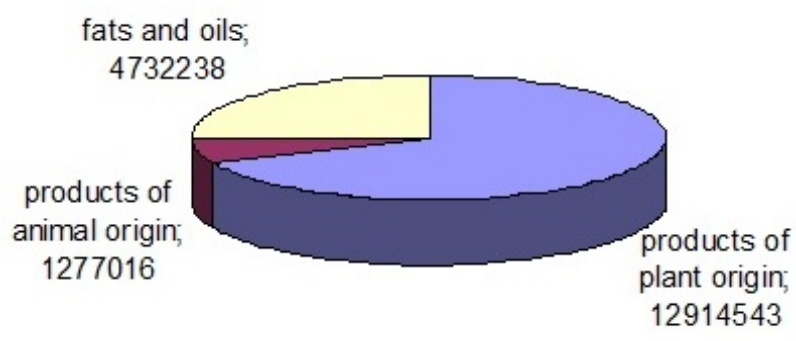

Fig. 2. The structure of Ukrainian agricultural exports in 2019 (in thousands of \$, according to the State Statistics Service of Ukraine).

Among products of plant origin, exports are significantly dominated by grain crops - almost $75 \%$. In 2019, they were exported from Ukraine worth \$ 9.63 billion.

Every year, Ukraine exports up to 60 million tons of grain crops, being the third largest exporter of grain in the world. Over the past 10 years, Ukraine has increased grain exports by almost 4 times. So in 2019, this figure was 56.7 million tons, and in monetary terms - almost 10 billion dollars. In terms of crops, grain exports in 2019 are represented by wheat, rye, corn, barley and a small amount of legumes.

It is important that according to the State Statistics Service of Ukraine, the sown areas under wheat and corn have remained virtually unchanged over the past five years. The increase in production of these crops is due to the gradual increase in their yield. For example, wheat productivity has increased by almost $20 \%$. In general, the average grain yield in 2019 increased by 2.2 quintals per hectare.

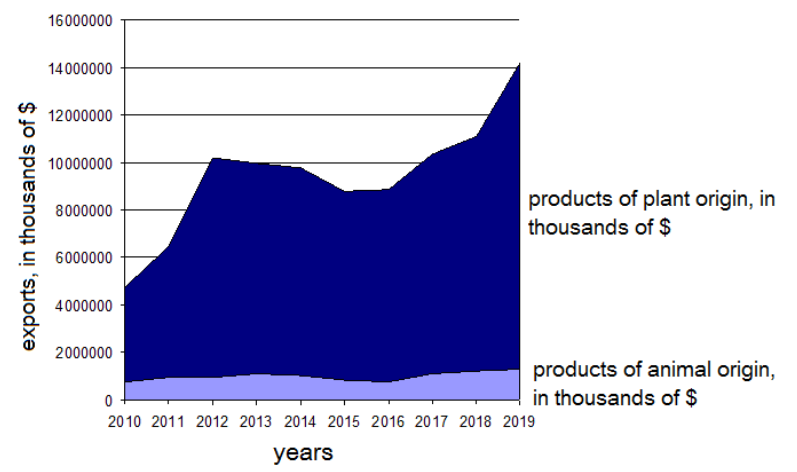

Fig. 3. Dynamics database providing export indicators of agricultural products having animal and vegetable origin from Ukraine in the period from 2010 to 2019 (according to the State Statistics Service of Ukraine).

According to the State Statistics Service of Ukraine, in 2019 the country exported oilseeds worth more than $\$ 2.5$ billion, which is $32 \%$ more than in 2018 . And the volume of export deliveries increased by more than $40 \%$ and amounted to 6.9 million tons. Here, Ukraine confidently holds a leading position in the world food market.

Exports of other plant products (vegetables, live trees and plants, edible fruits and nuts, etc.) from Ukraine are also growing steadily, however, in view of their small volumes, their impact on overall exports is minimal.

Ukraine is a world leader in the supply of sunflower oil to foreign markets. Thus, Ukraine's share in the world exports of sunflower oil amounted to $54.9 \%$ in 2019 . For comparison, Russia's share in this market at the end of the season was $26.2 \%$, Argentina $-6.2 \%$, the European Union $-5.1 \%$, Turkey $-3.3 \%$. And this occurs despite the fact that the world exports of sunflower oil for the season increased to 11.49 million tons, which is $15 \%$ higher than in 2018. Accordingly, Ukraine increased product supplies to foreign markets by $14 \%$ up to 6.04 million tons, which in monetary terms amounted to almost $\$ 4.7$ billion. Unfortunately, most of the sunflower oil comes from Ukraine as a raw material, after which it is refined and bottled under local brands. As a result, Ukrainian sunflower oil is sold abroad at a price 3-5 times higher than the purchase price.

The share of animal products in the structure of agricultural exports from Ukraine is extremely small. Despite some growth observed for this group of goods in the period 2017-2019, their contribution does not exceed 
$7 \%$. Such a small share in exports is primarily due to the industry low development level. And if the country's crop products are produced in excess, the domestic demand for livestock products is covered by imports from other countries.

The significant decline in exports of this group, which was observed in the period $2014-2016$, is primarily due to the closure of the Russian market. For example, if the products of animal origin at worth $\$ 559.5$ million were exported to Russia in 2012 , then only at $\$ 1.7$ million in 2016.

The main exports of animal products are meat (55\%) and dairy products $(36 \%)$, including poultry eggs and natural honey (Fig. 4). The share of other products does not exceed $3-5 \%$.

Meat in exports is represented mainly by meat and edible poultry offal. In 2019 , this is more than $90 \%$ of all exported meat. According to the results of 2019, Ukraine has become one of the top three exporters of poultry meat to the European Union countries. 134,262 tons of poultry meat were exported, which is $8.6 \%$ more than in 2018 . And as the current results of 2020 show that Ukrainian producers continue to increase their sales abroad.

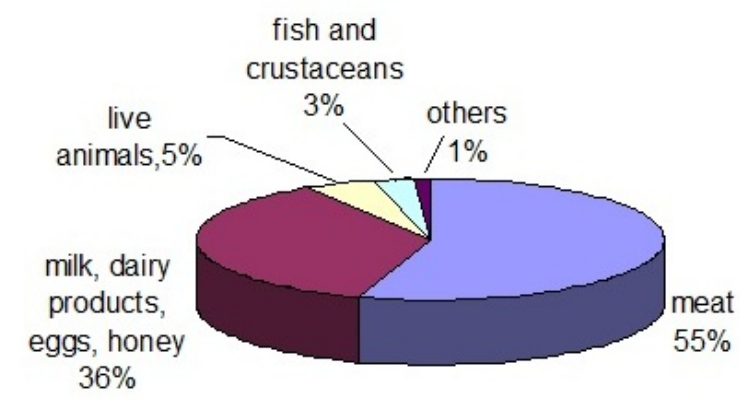

Fig. 4. Structure of livestock exports, 2019 (according to the State Statistics Service of Ukraine).

Next in weight in the structure of exports are a group of goods milk (dairy products), poultry eggs and natural honey. Within this group, about $30 \%$ are exports of honey, $23 \%$ - exports of chicken eggs and $22 \%$ - exports of milk and dairy products.

Ukraine ranks first in Europe and fifth in the world in terms of honey production. Annually, Ukraine produces about 100 thousand tons of honey, which is $6 \%$ of the world output. As a result, our country is one of the top exporters of this product.

The geography of agricultural exports from Ukraine has undergone significant changes in recent years. Thus, if until 2014 the CIS countries, including Russia, were one of the main consumers of Ukrainian agricultural products (up to $40 \%$ ), then as can be seen from the diagram shown in Fig. 5, in 2019 this figure is slightly higher than 7\%, as in 2018. This is due to the fact that since 2014, in connection with Russia's aggression, Ukrainian farmers have worked hard to find new markets.

Today, Asian countries are key partners of Ukraine in this area. Purchases of agricultural products by Asian countries in 2019 increased by almost $18 \%$ (to $\$ 9.4$ illion) and amounted to $42.6 \%$ of total agro-exports of Ukraine.

The volume of agricultural products to African countries increased by $43 \%$ and amounted to $14.2 \%$ (about $\$ 3.3$ billion) in 2019 [16,17].

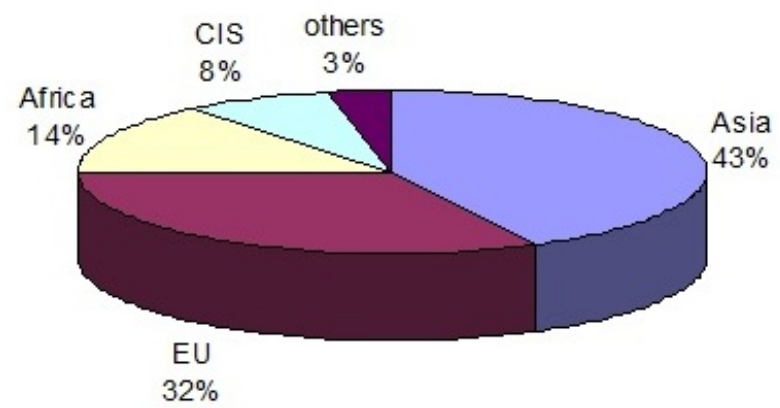

Fig. 5. Geography of agricultural products exports from Ukraine (according to the State Statistics Service of Ukraine).

If analyzed by country, the main consumers of Ukrainian agricultural products are China and Egypt. In 2019, these countries (as well as Turkey) increased the volume of purchasing these products by almost 1.5 times. As a result, they pushed to third place India, which for three years was the leader in this list. In addition to these countries, the main consumers of Ukrainian agricultural products are Turkey, the Netherlands, Spain, Germany, Poland, Italy and Belarus.

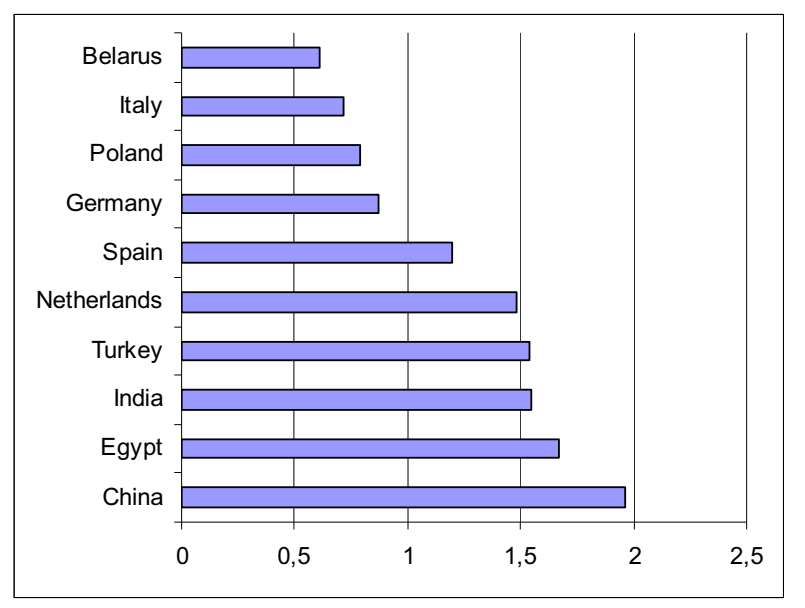

Fig. 6. The main importers of agricultural products from Ukraine in 2019 (in billion dollars, according to the State Statistics Service of Ukraine).

The formation of agricultural production specialization is determined primarily by the natural and climatic features of the region and its resource potential in their interaction with socio-economic factors [3]. The result is the territorial specialization of agricultural production. All this, no doubt, should affect the specialization of the agricultural export potential in the regions of Ukraine. Let's analyze this.

The map analysis of the agricultural export volume by regions of Ukraine (according to 2019) clearly 
demonstrates the spatial differentiation of this indicator (Fig. 7).

Thus, the regions with the highest indicators of agricultural exports geographically form an "axis" stretching from south to north (Odessa, Mykolaiv, Vinnytsia and Kyiv Regions). Further to the east are regions with average exports of agricultural products. Western regions are characterized by low rates. This includes the eastern regions of the country (Donetsk and Luhansk Regions), but this is due primarily to their partial occupation, as well as hostilities.

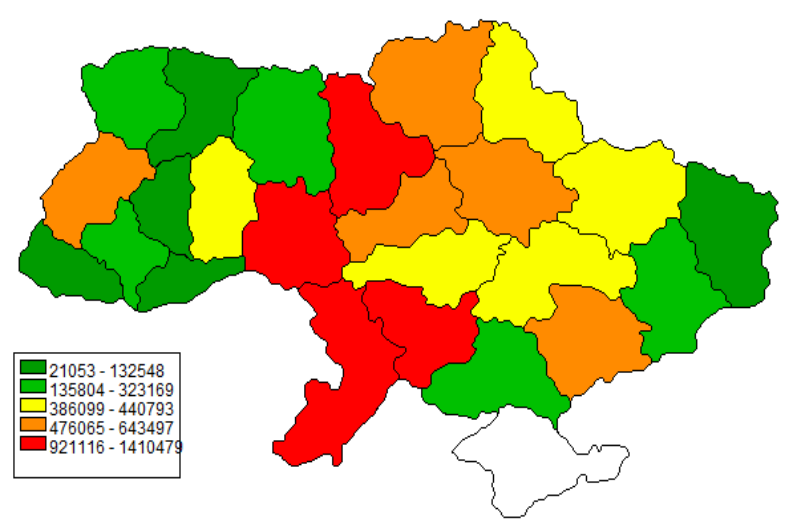

Fig. 7. The size of agricultural exports from the regions of Ukraine in 2019 (in \$ thousands, according to the State Statistics Service of Ukraine).

The geography of plant products exports from Ukraine is quite remarkable (Fig. 8). Thus, the regions with the largest exports of these products (Kyiv, Vinnytsia, Odesa and Mykolayiv Regions) form the same conditional vertical "axis", which divides the territory of Ukraine into two symmetrical parts. Around this "axis" are areas with average exports of crop products (Zhytomyr, Chernihiv, Cherkasy, etc.). At a distance from the "axis", in the west and east of the country, are the areas with the lowest exports of plant products (Transcarpathian, Volyn, Donetsk, Luhansk, etc.) The exceptions are Lviv and Zaporizhia Regions.

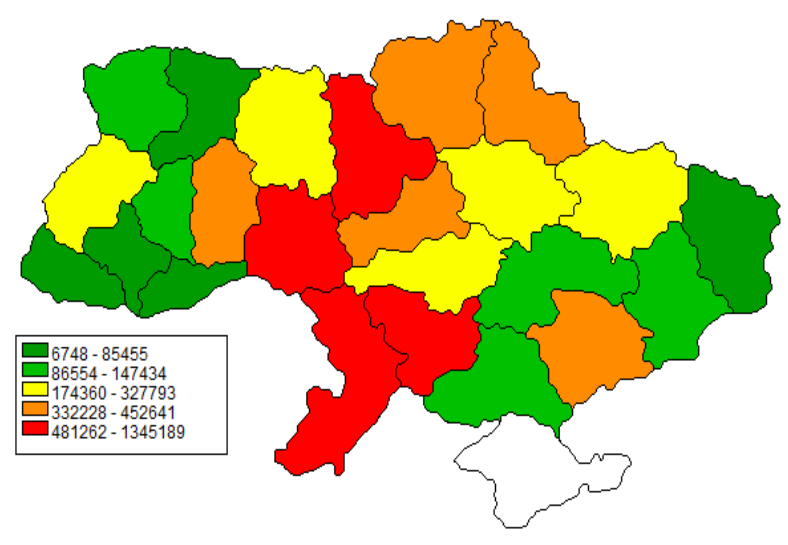

Fig. 8. Exports of plant products from the regions of Ukraine in 2019 (in thousands of \$, according to the State Statistics Service of Ukraine)
Such a symmetrical model of spatial differentiation reflects a very ambiguous interaction of natural-climatic and socio-economic factors that determine the specialization of crop production in Ukraine.

Thus, the regions with the same natural and climatic conditions (for example, Vinnytsia and Kirovohrad Regions) differ significantly in export indicators. The main reason for this is economic one. Obviously, the conditions for favorable development of farming are being created in different ways. This means both purely organizational and financial support for this sector of agriculture.

As for livestock products, the picture is much more complicated (Fig. 9). The core of the regions with the largest export indicators (Kyiv, Vinnytsia and Cherkasy Regions) is clearly distinguished in the center of the country. Most poultry farms, which provide the bulk of exports of these products, are concentrated here. Indicators in other regions are distributed very unevenly, without any patterns.

Analyzing the geography of animal or vegetable fats or oils exports by Ukraine's regions (Fig. 10) it is clear that the regions with the highest indicators (Vinnytsia, Kirovohrad, Cherkasy and Dnipropetrovsk Regions) are in the center of the country. The regions with average indicators are located to the south (except for Kherson Region) and to the east (except for Luhansk Region). Western regions have the lowest values of exports of this type (except for Lviv Region).

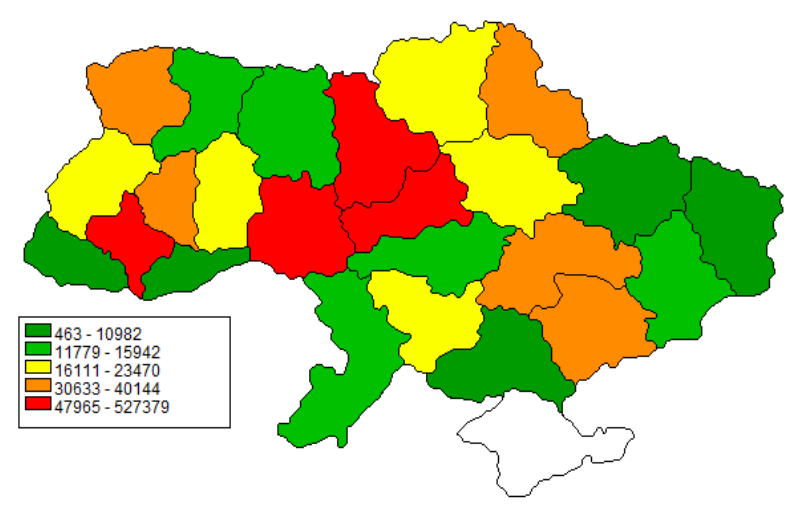

Fig. 9. Exporting products of animal origin from the regions of Ukraine in 2019 (in thousands of \$, according to the State Statistics Service of Ukraine)

In general, this zoning corresponds to the natural and climatic characteristics of the regions, which allows to grow oilseeds and, above all, sunflower. High performance in Lviv Region is mainly due to the presence of a large number of commercial entities engaged in the resale these products abroad from the central regions. At the same time, Kherson Region does not use its potential, as well as for the export of other agricultural products.

In order to identify specialization in the exports of agricultural products of the Ukrainian regions, a triangular diagram was made, which shows the ratio of the three main types of products in the exports of Ukrainian regions in 2019 (Fig. 11). The analysis of the diagram allows to establish 4 types of specialization in agricultural exports of Ukrainian regions. 
The first type includes the areas with a predominance in the animal origin products. These are: Kyiv, IvanoFrankivsk, Ternopil, Volyn and Rivne Regions.

The second type is the areas with a predominance in exports of plant products. These include: Chernihiv, Zhytomyr, Zakarpattia, Mykolaiv, Sumy, Kherson and Chernivtsi Regions.

The third type is the areas with a predominance in the export of animal or vegetable origin fats and oils. These include: Dnepropetrovsk, Lugansk, Donetsk and Kirovograd Regions.

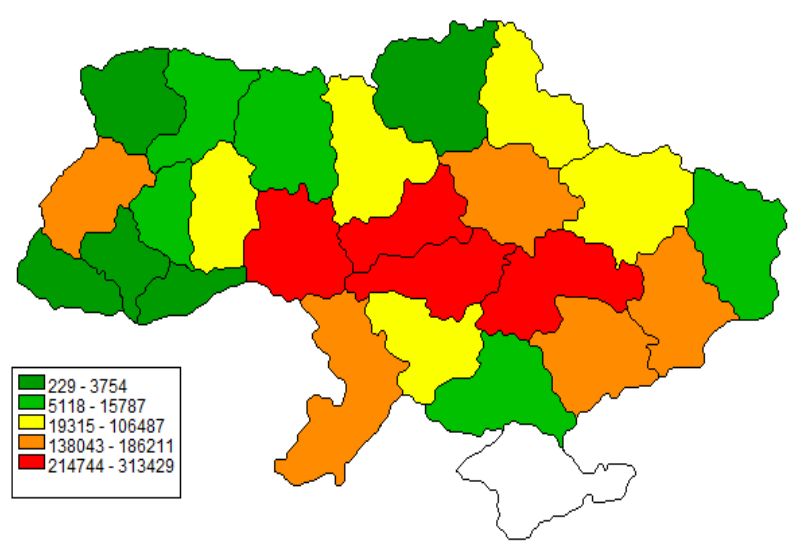

Fig. 10. Exporting fats and oils of plant and animal origin from the regions of Ukraine in 2019 (in \$ thousands, according to the State Statistics Service of Ukraine)

The fourth type includes the areas with mixed export specialization, mainly vegetable products, as well as fats and oils. These are: Odessa, Kharkiv, Poltava, Cherkasy, Lviv, Vinnytsia and Zaporizhia Regions.

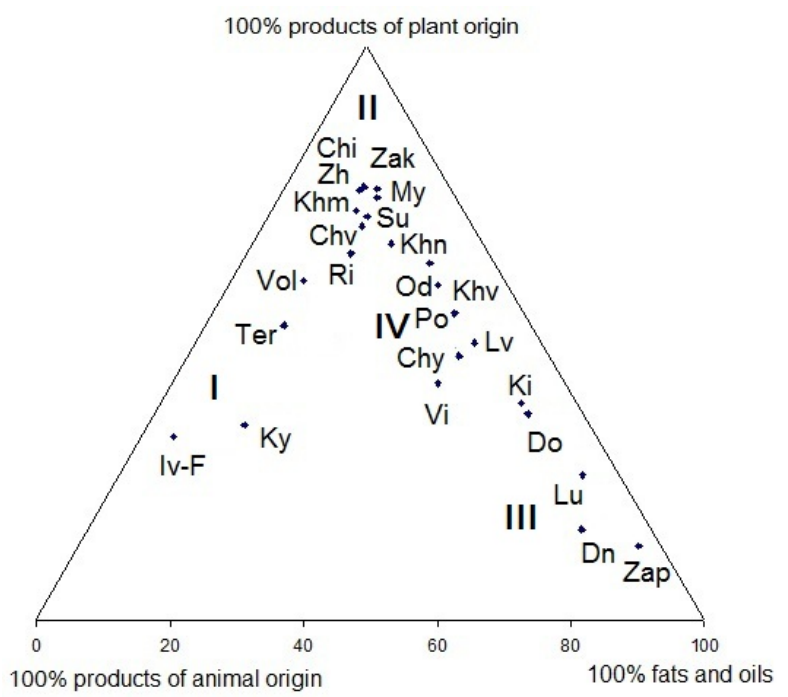

Fig. 11. Specializations in the agricultural export of the Ukrainian regions in 2019 (according to the State Statistics Service of Ukraine)

Spatial localization analysis of each specialization type allows to draw the following conclusions:

1. Products of animal origin dominate the exports of the western Ukrainian regions. The exception is the Kyiv region, in the export of which the products of poultry farms play an important role.

2. Regions whose exports are dominated by fats and oils are localized in the form of a strip stretching from the center of Ukraine to the east.

3. The areas with exports of products mainly of vegetable origin are located in the form of a strip extending from the southwest to the northeast of Ukraine and partly in the southern region of the country.

4. The regions with a combined specialization type of agricultural exports are located in the central and southern parts of Ukraine. The exception is Lviv Region, which specializes in customs transit of products abroad.

Table 1. summarizes data on the value of agricultural export indicators of Ukrainian regions with specialization types. Its analysis allows us to draw the following conclusions:

1. According to the value indicators of agricultural exports, all regions can be divided into three groups:

- the regions with the largest value of agricultural exports over \$ 500 million (Kyiv, Mykolaiv, Vinnytsia, Cherkasy, Lviv, Odesa, Zaporizhia);

- the regions with an average export value of agricultural products from $\$ 150$ to $\$ 500$ million (Zhytomyr, Khmelnytsky, Sumy, Chernihiv, Dnipropetrovsk, Donetsk, Kirovohrad, Kharkiv, Poltava);

- the regions with the smallest value of agricultural exports from $\$ 150$ to $\$ 500$ million (Ivano-Frankivsk, Ternopil, Rivne, Volyn, Zakarpattia, Kherson, Chernivtsi, Luhansk).

Table 1. Correlating the values of agricultural export indicators of Ukrainian regions with export specialization.

\begin{tabular}{|c|c|c|c|}
\hline $\begin{array}{c}\text { Agricultural } \\
\text { products } \\
\text { that } \\
\text { dominate } \\
\text { exports }\end{array}$ & \begin{tabular}{|c|} 
Areas with \\
the value of \\
agricultural \\
exports \\
over \$500 \\
million
\end{tabular} & $\begin{array}{l}\text { Areas with the } \\
\text { value of } \\
\text { agricultural } \\
\text { exports from } \$ \\
150 \text { to } \$ 500 \\
\text { million }\end{array}$ & $\begin{array}{l}\text { Areas with an } \\
\text { export value of } \\
\text { agricultural } \\
\text { products less } \\
\text { than } \$ 150 \\
\text { million }\end{array}$ \\
\hline $\begin{array}{c}\text { Live } \\
\text { animals, } \\
\text { products of } \\
\text { animal origin }\end{array}$ & Kyiv Region & - & $\begin{array}{c}\text { Ivano- } \\
\text { Frankivsk, } \\
\text { Ternopil, Rivne, } \\
\text { Volyn Regions }\end{array}$ \\
\hline $\begin{array}{l}\text { Vegetable } \\
\text { products } \\
\text { origin }\end{array}$ & $\begin{array}{l}\text { Mykolaiv } \\
\text { Region }\end{array}$ & $\begin{array}{c}\text { Zhytomyr, } \\
\text { Khmelnytsky, } \\
\text { Sumy, } \\
\text { Chernihiv } \\
\text { regions }\end{array}$ & $\begin{array}{c}\text { Transcarpathian, } \\
\text { Kherson, } \\
\text { Chernivtsi } \\
\text { Regions }\end{array}$ \\
\hline $\begin{array}{c}\text { Fats and oils } \\
\text { of animal or } \\
\text { vegetable } \\
\text { origin } \\
\end{array}$ & - & \begin{tabular}{|c} 
Dnipropetrovsk, \\
Donetsk, \\
Kirovograd \\
Regions \\
\end{tabular} & Luhansk Region \\
\hline Combined & $\begin{array}{l}\text { Vinnytsia, } \\
\text { Cherkasy, } \\
\text { Lviv, } \\
\text { Odessa, } \\
\text { Zaporozhye } \\
\text { Regions }\end{array}$ & $\begin{array}{c}\text { Kharkiv, } \\
\text { Poltava Regions }\end{array}$ & - \\
\hline
\end{tabular}

2. The regions with mixed (fourth) type of specialization have the highest export rates. Exceptions are Kiev (the first type - the dominance of animal products) and Mykolaiv (the second type - the dominance of crop production). 
3. The lowest indicators of exports are the regions with a predominance of animal origin products (the first type of specialization) and plant origin (the second type of specialization).

4. Areas of the third specialization type (fats and oil) belong mainly to the regions with average values of agricultural exports.

According to these criteria, the geography map of agricultural exports from Ukraine's regions was built, combining indicators of the total exports value and its specialization (Fig. 12). In fact, it reflects the results of interacting natural and climatic features of the regions and their resource potential with socio-economic factors. It is clear that:

- the central and southern regions of Ukraine have the greatest potential in the development of agricultural exports;

- an exception from this rule is Kherson Region, which is the result of socio-economic factors impact and, above all, insufficient attention from the regional leadership and farms to the development of this extremely important area of the region and the country as a whole;

- to increase the export of agricultural products in these regions it is required to have a balanced combination of crop production (mainly grain) and the cultivation of oilseeds. Thus in the Kirovograd, Dnipropetrovsk and Donetsk areas, for today, it is necessary to make an emphasis first of all, on grain, and in Mykolaiv Region on oil crops;

- in Zakarpattia and Chernivtsi Regions for increasing agricultural products exports there should be paid more attention to the development of animal husbandry.

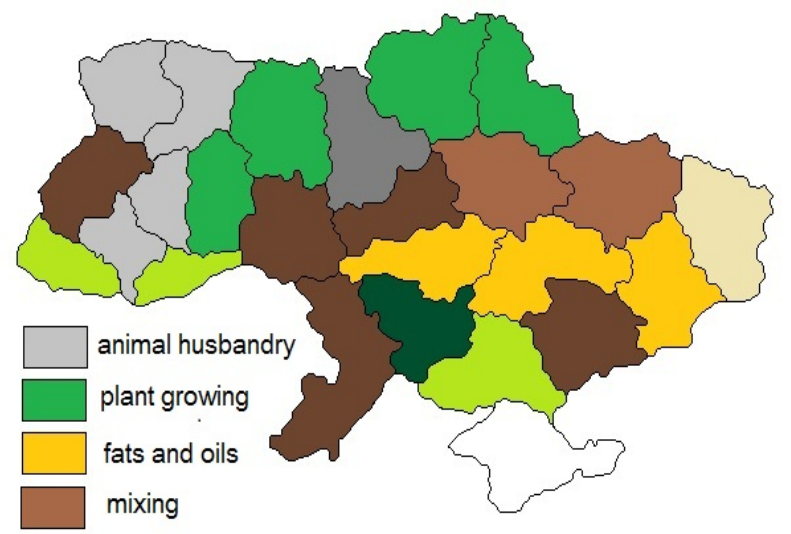

Fig. 12. The geography map of agricultural exports from the Ukrainian regions (according to the State Statistics Service of Ukraine) in 2019. The colors reflect the types of export specialization (4 types), and their intensity - the total value of agricultural exports in the region (3 groups).

\section{Conclusions}

As a result of the research performed it was established the following:

Agriculture has recently become one ofthe leading sectors of Ukraine's economy, currently providing up to $50 \%$ of foreign exchange earnings from exports of all goods from the country.
Given the dynamic characteristics of the agricultural exports growth from Ukraine, we can assume that the country in the coming years may become one of the most important players in the world market of agricultural products.

In the structure of Ukrainian agricultural exports, the majority are crop products $(68 \%)$, fats and oils $(25 \%)$, and animal products (only $7 \%$ ).

Four specialization types of agricultural exports from Ukrainian regions are established: the first type is the areas with dominance in the exports of animal origin products; the second type is the areas with dominance in the exports of plant products; the third type is the area dominated by exports of animal or vegetable origin fats and oils and the fourth type is the area with a mixed specialization of exports, mainly products of vegetable origin, as well as fats and oils.

The geographical analysis of agricultural exports from the Ukrainian regions allowed to develop recommendations for the re-profiling of agricultural production in a number of the country's regions in order to increase exports of this product type.

In this way, by agricultural products geography export expansion Ukraine will be able to create a competitive, export-oriented agricultural industry, and food-processing industry would produce competitive foodstuffs in accordance with the international safety and quality standards. In the result of these transformations, Ukraine will strengthen its positions at the traditional export markets and will trade its new export products with new partnership countries, which will facilitate positive farm products balance of trade. This, in turn, will have a positive impact on the development of our country's economy agrarian sector.

\section{References}

1. FAO, IFAD, UNICEF, WFP, WHO, The State of Food Security and Nutrition in the World. (FAO, Rome, 2019)

2. O. Antoniuk, P. Antoniuk, V. Lysiuk, Ek. Kh.Pr. 9(3), 9-15 (2017).

3. N. I. Mezentseva, O. M. Trusii, Heohrafiia AhrarnoPromyslovoho Kompleksu (Geography of the Agrarian-Industrial Complex) (VydavnychoPolihrafichnyi Tsentr Kyivskyi Universytet, Kyiv, 2016), 92 p.

4. N. A. Karasova, Ek. 8, 41-48 (2016)

5. S. A. Nadvynychnyi, Ek. A. 28(3), 56-61 (2018).

6. M. I. Puhachov, B. V Dukhnytskyi, V. M. Puhachov, Perspektyvni Napriamy Eksportu Ahroprodovolchoi Produktsii Ukrainy 20 Providnykh Krain-Importeriv Pshenytsi (Promising Areas of Ukrainian Agro-Food Products Export: 20 Leading Countries-Importers of Wheat) (NNTs IAE, Kyiv, 2013), 28 p.

7. Yu. O. Lupenko, M. I. Puhachov, Formuvannia Hlobalnoho I Rehionalnoho Rynkiv Silskohospodarskoi Syrovyny Ta Prodovolstva (Formation of Global and Regional Markets of 
Agricultural Raw Materials and Food) (NNTs IAE, Kyiv, 2015), 320 p.

8. Derzhavna Mytna Sluzhba Ukrainy (State Customs Service of Ukraine), https://customs.gov.ua. Accessed 30 Dec 2020.

9. Derzhavna Sluzhba Statystyky Ukrainy (State Statistics Service of Ukraine), http://ukrstat.gov.ua. Accessed 30 Dec 2020

10. Derzhavna Fiskalna Sluzhba Ukrainy (State Fiscal Service of Ukraine), http://sfs.gov.ua. Accessed 30 Dec 2020.

11. V. Hrytsevych, Statystychni Metody v Suspilnii Heohrafii (Statistical Methods in Public Geography) (Lvivskyi Natsionalnyi Universytet Imeni Ivana Franka, Lviv, 2016), 92 p.

12. Informatsiino-Analitychnyi Portal APK Ukrainy (Information-Analytical Portal of AIC of Ukraine), https://agro.me.gov.ua. Accessed 30 Dec 2020

13. Statistics Division of Food and Agriculture Organization of the United Nations, http://www.fao.org/faostat. Accessed 30 Dec 2020

14. United Nations World Food Programme, http://www.wfp.org. Accessed 30 Dec 2020

15. I. V. Kholoshyn, Pedahohichna Heoinformatyka. Ch. 3. Heoinformatsiini Systemy (Pedagogical Geoinformatics. Part 3. Geographic Information Systems) (Vydavets FOP Cherniavskyi D. O., Kryvyi Rih, 2016), 176 p.

16. A. Asmare, Y. Markku, African Journal of Agricultural Research 11 (2) (2018)

17. J. Shen, H. Tang, J. Liu, Chilean Journal of Agricultural Research 80 (1) (2020) 